\title{
Aikuiskouluttajan tehtävä on herättää oppijassa harrastus henkiseen kasvuun
}

Jukka Tuomisto \& Petri Salo (toim.) (2006 ). Edistävä ja viihdyttävä aikuiskasvatus. Tampere University Press.

Jukka Tuomiston ja Petri Salon toimittamassa teoksessa "Edistävä ja viihdyttävä aikuiskasvatus” tarkastellaan perusteellisesti professori Aulis Alasen toimintaa suomalaisen aikuiskasvatuksen parissa niin alan käytännön ja teorian kehittäjänä, tutkijana kuin yliopisto-opettajanakin. Suomessa ei ole toista henkilöä, joka olisi tutkinut sivistysjärjestöjen toimintaa yhtä pitkään ja yhtä syvällisesti kuin Alanen. Hän pohti ja kehitti alan keskeisiä ongelmia yhä uudestaan erilaisista näkökulmista ja ajankohdista tarkasteltuna (mukaan luettuna kansainvälisyys). Teoksen eräänä tavoitteena onkin antaa näkemyksiä jokaiselle aikuiskouluttajalle siihen, miten Alasen ajatukset soveltuvat nykyisen aikuiskasvatustodellisuuden analysoinnin välineiksi. Tähän viitekehykseen tartun itsekin ja tarkoituksenani on tuoda esiin, miten Alasen monet opit ovat edelleen ajankohtaisia ja käyttökelpoisia nykyisten aikuisohjaus- ja neuvontatyön käsitysten mukaan.

\section{Sivistystyön mahdollisuu- det ja velvoitteet}

Alanen tutki koko aikuiskasvatustieteen olemusta, joskin hänen intressinsä keskittyivät erityisesti vapaan sivistystyön toimintaan, sen praktisen teorian kehittämiseen. Alanen piti itsestäänselvänä, että ihminen kykenee oppimaan uutta ja kehitty- mään vielä aikuisiällä. Tästä syystä Alanen asetti suuria vaateita ja odotuksia vapaalle sivistystyölle. Hän kannatti korostuneesti järjestynyttä, arvoille perustuvaa, opinnollista, tietoista ja tavoitteista aikuiskoulutusta. Hänen mukaansa mikä tahansa virikkeellinen toiminta ei kasvattanut tai jalostanut ihmistä. Alanen ei ollut informaalisen oppimisen puolestapuhuja. Laulukuoroja, liikuntakerhoja ja käsityöpiirejä tarvittiin, mutta niihin oli sisällytettävä riittävästi esimerkiksi kirjallisuuteen perustuvaa tietopuolista opiskelua.

Alanen korosti ihmisläheistä, itseisarvoista aikuiskasvatusta, jonka perusta on opiskelijan omissa valinnanmahdollisuuksissa. Tarve tämänsuuntaiseen vahvistamiseen korostuu nykyaikana, koska työelämän henkilökohtaiset vaatimukset ja talouden kilpailukyvyn edistämiseen liittyvät paineet korostavat hyödylliseksi nähdyn formaalin opiskelun merkitystä suhteessa non-formaaliin ja informaaliin oppimiseen. Nykyisin kohdistuu kuitenkin suuri vaatimus formaalin koulutuksen ulkopuolella tapahtuvan opitun tunnistamiseen ja tunnustamiseen (esimerkiksi Aiemmin hankitun osaamisen tunnistaminen korkeakouluissa/OPM työryhmämuistioita ja selvityksiä 2007:4). Ongelmana onkin, että opitun muodollinen hyväksyntä ja itsearvoinen oppiminen eivät vielä kohtaa tai ovat risti- riidassa keskenään. Alasta koskevasta teoksesta löytyy hyvää pohdittavaa siihen, olisiko kansanomaisen opetuksen tarve nykyisin siinä, että opetusjärjestelyissä kohdistettaisiin enemmän huomiota syrjäytyneisiin ja syrjäytymisuhan alla oleviin ihmisiin. Tällöin opitun tunnustamisen lisäksi tunnustettaisiin myös jokaisen ihmisen oma ihmisarvo.

\section{Aito välittäminen}

Alasen mielestä vapaan sivistystyön perustehtävä on ihmisen kokonaispersoonallisuuden tasapuolinen kehittäminen. Kokonaispersoonallisuudella Alanen käsitti yksilön kehittymisen tiedollisesti, taidollisesti, eettisesti ja esteettisesti sekä kansalaisena että ammattiroolinsa toteuttajana. Alanen piti luovuttamattoman tärkeänä sitä, että vapaan sivistystyön koulutukseen hakeutuvilla täytyy olla ”aito ja vaivannäköön valmis pyrkimys”. Aikuisopiskelu ei saanut olla vain tiettyjen erityistietojen ja -taitojen kapea-alaista hankkimista. Esteettisyyttä eri ammattialoilla on pohdittu hyvin samansuuntaisesti teoksessa Ammattiin kutsu (OPM artikkelijulkaisu 2006: 18). Esteettisyys työssä ylittää rutiinin, välinpitämättömyyden ja mitäänsanomattomuuden rajan ja tuottaa sekä tekijälleen että teon kohteelle kokemuksen välittämisestä.

Alanen pohti vapaan sivistystyön opintoihin osallistuvien kahtalaisia tavoitteita. Opiskelijoilla oli sekä opinnollisia että viihdyttäviä yhdessäoloon 
liittyviä tavoitteita. Alaselle opinnollisuus meni aina viihtyvyyden edelle. Opinnollisuudella Alanen tarkoitti tiedollisen aktiivisuuden virittymistä ja opintovalmiuksia. Opinnollisia tavoitteita edustivat mm. ammattipätevyyden lisääminen, hyödylliset vapaa-ajan taidot sekä yleissivistyksen parantaminen.

\section{Viihteellisyys yksin passivoi}

Viihtymistavoitteita olivat virkistävä vapaa-ajan vietto, yhdessäolo ja ajatusten vaihtaminen. Viihteellisyys merkitsi Alaselle ennen kaikkea ei-opinnollista ja ei-tavoitteista, lyhytjänteistä ja ensisijaisesti sosiaalista tyydytystä tuottavaa toimintaa. Siihen liittyi Alasen mukaan näennäisopiskelun vaara eli tavoitteiden ja toimintavalmiuden vastaamattomuuden ongelma, jolloin muka pelkkä osallistuminen opintoihin johtaisi tavoitteiden saavuttamiseen. Alasen mukaan viihteellinen toiminta lisää osallistujien passivoitumista aktivoitumisen sijasta ja ajautumista yhä kauemmaksi aikuiskasvatuksen tavoitteista. Spinozan ilon filosofian mukaisesti Alanen korostaa ihmisen tyytyväisyyden syntyä asioiden hallitsemisen tunteesta.

\section{Sosiaalisuus ja kuulumi- nen ryhmään}

Edellisestä huolimatta Alanen ei suinkaan väheksynyt sosiaalisuutta ja sen merkitystä opiskelussa. Sosiaalisuudella on keskeinen vaikutus opintokerhon yleiseen ilmapiiriin, yhteisöllisyyteen ja opinnollisuuteen. Sosiaalisten tavoitteiden edistäminen vapauttaa osallistujat epä- varmuuden, voimattomuuden ja eristyneisyyden kokemuksista. Alanen korosti, että ryhmä oli aktivoitava samanaikaisesti sekä työskentelynsä suunnitteluun yhteisesti että yksilölliseen omatoimisuuteen. Ryhmätoimintaa oli määrätietoisesti ohjattava. Itse hyödynnän aikuisopiskelijoiden ohjauksessa ryhmää ja ryhmädynaamisia ilmiöitä, jolloin tehtävä- ja tunnetavoitteet muodostuvat yhtä tärkeiksi, ja uskon, että ihmiselle tärkeä "johonkin ryhmään kuulumisen tunne” edistää opinnollisten tavoitteiden saavuttamista.

Alasen mukaan aikuiskouluttajien tehtävä on vaativa ja syvällinen, jotta opiskelija antautuu omaehtoisen oppimisen periaatteelle. Aikuiskouluttajilla on oltava vahva teoreettinen ja kokemuksellinen osaaminen opettamastaan aiheesta (malli opiskelijalle). Heidän on osattava rakentaa luottamussuhde opiskelijoiden kanssa, ts. toimittava opiskelijalähtöisesti ottaen huomioon opiskelijoiden persoonallisuudet. Aikuiskouluttajien tehtävänä on herättää opiskelijoiden "harrastus" henkiseen kasvuun. Alanen korosti kuitenkin, että aikuiskouluttajien tulee olla realistisia omassa työssään ja tavoitteissaan. Ihmiset eivät hetkessä muutu todellisiksi persoonallisuuksiksi. Lisäksi aikuisen kehityspsykologiset edellytykset tuovat oman lisänsä oppimistavoitteisiin.
Tehokkuus opetus- ja oppimisprosessiin

Alanen oli myös aikuiskasvatuksen laadun ja arvioinnin uranuurtaja. Alasen laatu- ja tehokkuusajattelu kohdistuivat opetus- ja oppimisprosessiin, ei niinkään sivistystyön taloudelliseen tuottavuuteen ja tehokkuuteen. Alanen ei halunnut, että aikuisopiskelija jää sivuosaan. Erilaisiin järjestelmiin (mm. laatujärjestelmät) Alanen suhtautui kriittisesti, koska ne johtavat hänen mielestään helposti organisaatiokeskeiseen ajatteluun. Alaselle laadun mittana oli opiskelijan edistyminen tietyistä lähtökohdista tiettyjen tavoitteiden suuntaan. Nykyiset ohjauskäsitykset (esim. Onnismaa 2007; Ohjausja neuvontatyö) korostavat juuri ohjaajan ja ohjattavan välistä prosessia, jossa tarkastellaan yhteisesti elämänsuunnittelun riski- ja eettisiä kysymyksiä. Keskittymällä ohjattavan henkilökohtaisiin merkityksiin ja elämänroolien rakentumiseen korostetaan Alasellekin tärkeiden arvojen merkitystä oppimisessa ja elämänsuunnittelussa.

Näihin ajatuksiin innostuin teoksessa niiden toimivuuden vuoksi. Suosittelen teosta aikuiskasvatuksen käsikirjaksi jokaiselle aikuiskoulutuksen parissa toimivalle.

\section{Tia Isokorpi}

